\title{
GETTING NORMATIVE: THE ROLE OF NATURAL RIGHTS IN CONSTITUTIONAL ADJUDICATION
}

\author{
Randy E. Barnett*
}

Our next question must be whether we can reconcile our natural law past with our textualist present-and whether we even want to.

\section{INTRODUCTION: THE NATURAL LAW REVIVAL}

We are in the midst of a natural law revival. Not since the Hart-Fuller debate ${ }^{2}$ in the wake of Nuremberg has legal academia witnessed such interest in the topics of natural law and natural rights. ${ }^{3}$ While this development may be only the most recent aspect of the now several decades old revival of normative legal philosophy that I chronicled some ten years ago, 4 the immediate cause of this interest was, of course, the nomination of Clarence Thomas to the Supreme Court of the United States. The

* Professor, Boston University School of Law. This paper was presented at the Conference on Liberalism, Modernity, and Natural Law, sponsored by the American Public Philosophy Institute, the Symposium on Rights sponsored by the philosophy department of the University of North Carolina at Greensboro, and to faculty workshops at Loyola Law School, Loyola Marymount University, Rutgers-Camden School of Law, and Boston University School of Law. Participants in these gatherings made many valuable suggestions for improvement. I also wish especially to thank Jules Coleman, Bob Bone and Richard Hyland for commenting on earlier drafts and Saba Khairi for her research assistance.

1. Suzanna Sherry, Natural Law in the States, 61 U. Cin. L. Rev. 171, 222 (1992).

2. See H.L.A. Hart, Positivism and the Separation of Law and Morals, 71 Harv. L. Rev. 593 (1958); Lon L. Fuller, Positivism and Fidelity to Law-A Reply to Professor Hart, 71 Harv. L. Rev. 630 (1958).

3. Three recent issues of law reviews have been largely devoted to the topic. See Natural Law Symposium, 38 Cleve. St. L. Rev. 1 (1990); Symposium: Perspectives on Natural Law, 61 U. Cin. L. Rev. 1-222 (1992); Commentary on Constitutional Positivism, 25 Conn. L. Rev. 831-946 (1993). The latter consists of papers responding to Frederick Schauer's article, Constitutional Positivism, 25 Conn. L. Rev. 797 (1993).

4. See Randy E. Barnett, Contract Scholarship and the Reemergence of Legal Philosophy, 97 Harv. L. Rev. 1223 (1984) (book review). 
influence of this event on the academic imagination grew out of what were actually a series of events.

First came the criticism of Supreme Court nominee and former Judge Robert Bork - most forcefully pressed by Senate Judiciary Chairman Joseph Biden-for failing to take seriously the background rights of citizens. Exhibit number one for Biden was Bork's now-famous comparison of the Ninth Amendment to an "ink blot" which appears on the Constitution. 5 Subsequent Supreme Court nominees were required to pledge their fealty to the constitutional principle that " $[t]$ he enumeration in the Constitution of certain rights shall not be construed to deny or disparage others retained by the people." 6 These events unleashed a scholarly excursion into the meaning of this neglected provision that was unprecedented in American legal history. 7 As a result, we can no longer ignore this unrepealed constitutional injunction on the grounds that it is a complete mystery. ${ }^{8}$

Before the dust from this interest in the "rights retained by the people" had settled, President Bush nominated for the Supreme Court Judge Clarence Thomas-a man who, in his speeches and writings, seemingly favored using natural law when interpreting the Constitution. ${ }^{9}$ As a result three rather startling events occurred in rapid succession. First, in complete contrast

5. See Nomination of Robert H. Bork to be Associate Justice of the Supreme Court of the United States: Hearings before the United States Senate Committee on the Judiciary 249 (1989) (testimony of Robert Bork):

I do not think you can use the ninth amendment unless you know something of what it means. For example, if you had an amendment that says "Congress shall make no" and then there is an ink blot and you cannot read the rest of it and that is the only copy you have, I do not think you the court make up what might be under the ink blot if you cannot read it.

6. U.S. Const. Amend. IX. For an appendix reproducing the testimony of Robert Bork, Anthony Kennedy, David Souter, and Clarence Thomas concerning the Ninth Amendment, unenumerated rights and natural law, see 2 Randy E. Barnett, ed., The Rights Retained by the People: The History and Meaning of the Ninth Amendment 427-508 (George Mason U. Press, 1993).

7. For a representative sample of this post-Borkian scholarly debate (and a bibliography of other Ninth Amendment scholarship), see id.

8. Not that this scholarship has prevented Bork himself from doing so. See Robert H. Bork, The Tempting of America: The Political Seduction of the Law 183 (Free Press, 1990) ("There is almost no history that would indicate what the ninth amendment was intended to accomplish.").

9. See, e.g., Clarence Thomas, The Higher Law Background of the Privileges or Immunities Clause of the Fourteenth Amendment, 12 Harv. J.L. \& Pub. Policy 63, 63-64 (1989):

[N]atural rights and higher law arguments are the best defense of liberty and of limited government. Moreover, without recourse to higher law, we abandon our best defense of judicial review-a judiciary active in defending the Constitution, but judicious in its restraint and moderation. Rather than being a justification of the worst type of judicial activism, higher law is the only alternative to the willfulness of run-amok majorities and run-amok judges. 
to the arguments used in opposition to Robert Bork, critics of Judge Thomas immediately reacted by characterizing his interest in natural law as kooky and outside the mainstream.10 Second, this fledgling campaign was then completely undercut by Chairman Biden's ringing endorsement of natural law in his opening statement during the hearings. Remaining true to his stance during prior hearings, Senator Biden endorsed the priority of natural law but said, for him, the important question to be answered by the hearings was which version of natural law the nominee adopted.11 By taking this stance, the other Democratic senators were effectively disabled from ridiculing the natural law position. Then, with the stage so dramatically set, Judge Thomas emphatically rejected the position he had seemingly endorsed and maintained that natural law had no role to play in constitutional adjudication, 12 thereby depriving Senator Biden of his debate over the proper version of natural law. Thus in a matter of weeks the natural law issue was forcefully laid upon the table for national consideration, and scholars then proceeded to continue the debate in the law reviews. ${ }^{13}$

10. The most noteworthy of these critics was Professor Laurence Tribe, who characterized Judge Thomas as "the first Supreme Court nominee in $\mathbf{5 0}$ years to maintain that natural law should be readily consulted in constitutional interpretation." Laurence $\mathbf{H}$. Tribe, 'Natural Law' and the Nominee, N. Y. Times, July 15, 1991, at A15. For a list of others who criticized Thomas' reliance on natural law, see Ken Masugi, Natural Right and Oversight: The Use and Abuse of "Natural Law" in the Clarence Thomas Hearings, 9 Pol. Communication 231, 235-37 (1992).

11. See Appendix B: Testimony of Recent Supreme Court Nominees Concerning the Ninth Amendment, Unenumerated Rights, and Natural Law, in Barnett, ed., 2 Rights Retained by the People at 489 (cited in note 6) (statement of Senator Biden):

And there's a third type of natural law, Judge. It's the one that mirrors how the Supreme Court has understood our Constitution for the bulk of this century. And it's the one that I believe most Americans subscribe to. It is this view of natural law that I believe-I personally, to be up front about it - think is appropriate. It is this view of natural law, the Constitution should protect personal rights falling within the zone of privacy, speech and religion the most zealously. Those rights that fall within that zone should not be restricted by a moral code imposed on us by the Supreme Court or by unjust laws passed in legislative bodies.

12. Although construing Thomas' writing as endorsing the use of natural law in constitutional adjudication is not unreasonable, his former aide and speech writer denies that he ever advocated such a practice. See Masugi, 9 Pol. Communication at $248 \mathrm{n} .45$ (cited in note 10) ("To my knowledge, Thomas in his pre-judicial writings never used the term constitutional adjudication."). For a defense of the coherence of this position, see Russell Hittinger, Natural Law in the Positive Laws: A Legislative or Adjudicative Issue?, 55 Rev. of Politics 5, 22 (1993) ("[T]here is nothing contradictory in arguing, on the one hand, for a natural law basis of government, and indeed of positive law itself, while at the same time holding that judges ought, whenever possible, to be bound by written law.").

13. See note 16 and accompanying text. The debate has even inspired a satire. See Mark Hamilton Levison and Charles Sherman Kramer, The Bill of Rights as Adjunct to Natural Law, 1991 Detroit Coll. L. Rev. 1267 (neither Hamilton nor Sherman are their middle names). 
In my view, this discussion has now reached a critical juncture. It has been established beyond any reasonable doubt that adjudication based on natural rights (as distinct from natural law14) is excluded neither by "textualist" nor by "originalist" approaches to constitution interpretation. The labored textual and historical arguments that have been presented to the contrary15 can be persuasive only to those who have not been exposed to the competing interpretations based, in part, on evidence omitted by the skeptics. 16

Still, the fact that adjudication based on natural rights is not refuted by text or history does not mean that it is therefore constitutionally justified. The time has come, therefore, to lay these important historical and textual debates to one side and face squarely the two questions posed by Suzanna Sherry at the conclusion of her most recent contribution and with which I began this essay: 17 is it possible today to include natural rights in the process of constitutional adjudication and is it desirable? In short, it's time to get normative.

14. More on this distinction anon.

15. See, e.g., Raoul Berger, Natural Law and Judicial Review: Reflections of an Earthbound Lawyer, 61 U. Cin. L. Rev. 5 (1992); Philip A. Hamburger, Natural Rights, Natural Law, and American Constitutions, 102 Yale L.J. 907 (1993); Thomas B. McAffee, The Original Meaning of the Ninth Amendment, 90 Colum. L. Rev. 1215 (1990); Thomas B. McAffee, The Bill of Rights, Social Contract Theory, and the Rights "Retained" by the People, 16 S.I.U. LJ. 267 (1992); Thomas B. McAffee, Prolegomena to a Meaningful Debate of the "Unwritten Constitution" Thesis, 61 U. Cin. L. Rev. 107 (1992); Helen K. Michael, The Role of Natural Law in Early American Constitutionalism: Did the Founders Contemplate Judicial Enforcement of "Unwritten" Individual Rights?, 69 N.C. L. Rev. 421 (1991). As this article goes to press Raoul Berger has weighed in with yet another article criticizing my previous arguments that the Ninth Amendment supports the judicial protection of the natural rights "retained by the people." See Raoul Berger, The Ninth Amendment, as Perceived by Randy Bamett, 88 Nw. U. L. Rev. 1508 (1994). Responding to his arguments here would be inappropriate, however, since I intend to put the historical issues that he discusses to one side for now so I may consider the normative question of how the Ninth Amendment and the Constitution generally ought to be interpreted.

16. See, e.g., Barnett, Introduction-Implementing the Ninth Amendment, in Barnett, ed., 2 The Rights Retained by the People at 1 (cited in note 6); Steven J. Heyman, Natural Rights, Positivism and the Ninth Amendment: A Response to McAffee, 16 S.I.U. L.J. 327 (1992); Calvin R. Massey, The Natural Law Component of the Ninth Amendment, $61 \mathrm{U}$. Cin. L. Rev. 49 (1992); David N. Mayer, The Natural Rights Basis of the Ninth Amendment: A Reply to Professor McAffee, 16 S.I.U. L.J. 313 (1992); Suzanna Sherry, The Founders' Unwritten Constitution, 54 U. Chi. L. Rev. 1127 (1987); Sherry, 61 U. Cin. L. Rev. 171 (cited in note 1); Bruce N. Morton, John Locke, Robert Bork, Natural Rights and the Interpretation of the Constitution, 22 Seton Hall L. Rev. 709 (1992). To date, I have not specifically responded to the subtle and intriguing historical analysis recently presented by Philip Hamburger. See Hamburger, 102 Yale L.J. 907 (cited in note 15). In what follows I briefly touch upon them twice. See notes 34 and 71 . However, as with Raoul Berger, most of Hamburger's historical claims are outside the scope of this article.

17. See note 1 and accompanying text. 
Professor Sherry's questions can be viewed as posing two distinct challenges. The first- "Can we take natural rights into account today?"-might be considered pragmatic or practical; the second-"Do we want to?"-might be viewed as more purely normative. I think this possible distinction is overdrawn. If we could not take rights into account, we surely would not want to. And the alleged reasons why we cannot are largely normative, not really practical in nature. Moreover, many would concede that we would naturally want to take natural rights into account if we could. At any rate, I intend to address both questions here. In this paper, I shall maintain that the correct answers to Suzanna Sherry's questions are "yes" and "yes." Constitutional adjudication both can and should take natural rights into account.

My argument can be summarized as follows:

(1) Those who enact laws to govern the conduct of citizens ${ }^{18}$ claim that (a) their laws are not unjust and (b) citizens have at least a prima facia moral duty to obey these laws.

(2) To assess whether these claims of lawmakers are warranted, it is appropriate to ask whether their enactments have the qualities that are requisite to being both just and binding.

(3) One of these qualities is that laws not infringe the background or natural rights retained by the people.

(4) Because citizens cannot assess every law to see if it has this rights-respecting quality, there must be some procedural assurance that someone sufficiently impartial has attempted such an assessment.

(5) To be legitimate, law-making processes established by a constitution must (among other things) provide such an assurance.

(6) In our constitutional scheme, the responsibility for providing this sort of scrutiny of enacted legislation falls to the judiciary.

(7) Therefore, background or natural rights should figure in judicial review of legislation.

(8) However, there are methods for performing this task that do not require judges to specify all the background or natural rights retained by the people.

Each step of this argument is contestable, and I shall not be able to establish all of them in this essay. My main purpose is to introduce the argument and defend its cogency.

18. I include in the term "citizens" all persons who are subject to the jurisdiction of constitutional authorities. 


\section{THE PROBLEM OF LEGITIMACY}

Getting normative requires a point of entry. We need to expose the largely hidden problem that normative analysis is intended to address. In the case of a normative analysis of the Constitution, a document that has achieved near mystical status in the United States, this question is almost taboo. It is a question based on an undisputed fact: the constitution is simply a piece of "parchment under glass." The question is: why should we or anyone else care about what it says? The need to answer this question is what I shall call here the problem of legitimacy.

"Legitimacy" can have many different meanings, so it is important for me to clarify how I am using this term. By "legitimacy," I do not mean the question of whether a particular law is "valid" because it was enacted according to the accepted legal process-e.g. the Constitution specifies that to be valid a law must be enacted by majorities of both houses of Congress and signed by the President-though some may use the term in this way. Nor do I equate the legitimacy of a law with its "justice," though these two concepts are closely related, or with the mere perception that a law is just. Rather, the concept of legitimacy that I am employing refers to whether the process by which a law is determined to be valid is such as to warrant that the law is just. That is, was a particular law made in such a manner as to provide some assurance that it is just? A law produced by such justiceassuring procedures is legitimate.

Thus, according to my usage, a valid law could be illegitimate; 19 and a legitimate law could be unjust. ${ }^{20}$ Nonetheless, the problem of legitimacy that I raise here links the process that determines legal validity in a particular legal system to the issue of justice. Although a constitutional process by which legal validity is determined need not (as a conceptual matter) take justice into account, legitimacy suggests that (as a normative matter) it ought to do so.21 For, as I shall explain in the balance of this paper, the

19. A law may be "valid" because produced in accordance to all procedures required by a particular lawmaking system, but be "illegitimate" because these procedures are inadequate to provide assurances that a law is just.

20. A law might be "legitimate" because produced according to procedures that assure that it is just, and yet be "unjust" because in this case the procedures (which can never be perfect) have failed.

21. - To the extent the issue is thought to be conceptual as opposed to normative, the traditional natural law-positivist debate is sterile. Even Aquinas was quite capable of distinguishing as a conceptual matter between those human laws that were just and those that were unjust when he declared that ". . . Laws framed by man are either just or unjust." Thomas Aquinas, Summa Theologica, in 20 Great Books of the Western World 233 (The Encyclopedia Britannica, 1952). Rather, for Aquinas and other natural law 
problem of legitimacy is to establish why anyone should care what a constitutionally valid law may command. The answer I shall give is that we should care and, consequently, may owe a prima facie duty to obey a law, only if the processes used to enact provide good reasons to think that it is just.

\section{THE FUNCTION OF THE CONSTITUTIONAL ENTERPRISE}

So why should anyone care about what is written on one particular document that lies under glass in Washington, D.C.? One reason-and the reason I shall focus on in this paper-is that the terms of this document are used to regulate an enterprise that will have a direct effect on those who live in the territory known as the United States of America.22 In particular, this document is used to regulate an enterprise which produces commands that others act or refrain from acting in a particular way. Certain human beings referring to themselves as members of a "duly constituted government" are going to be telling you and me what to do. Drive on the right side of the road. Don't kill or rape anyone. Pay a percentage of your income in "taxes." Don't smoke marijuana or inhale cocaine.

Most important, these persons not only threaten to sanction us in some way for disobedience, but they also claim that (a) they are justified in imposing sanctions coercively upon us and (b) we have a moral duty to obey their "lawful" commands-that we would be acting wrongly by breaking the commands they call "laws." In sum, they claim right as well as might and rest this claim in important part on the fact that they are authorized to issue commands by a piece of parchment they call the "Constitution." So we are entitled to ask, what (if anything) it is about this paper that gives their commands the binding authority they claim?

Look at the matter another way. The Constitution is supposed to be the guiding blueprint for just another human enter-

thinkers, the issue of lawfulness is not conceptual as it is for modern positivists, but normative. Only just laws "have the power of binding in conscience ...." Id. It is this issue of "binding in conscience" that informs his endorsement of Augustine's statement that " 'that which is not just seem to be no law at all;' therefore the force of a law depends on the extent of its justice." Id. at 227 (emphasis added).

22. That, at least, is the theory. The normative argument presented here rests in the assumption that the enterprise of lawmaking is really governed by the provisions of the Constitution. To the extent that significant provisions of the Constitution have been either ignored or interpreted out of existence, this assumption and the normative argument that rests upon it is undermined. 
prise that is producing a good or service for human consumption. In this case the product is law. But unlike other enterprises, this one purports to have the rightful or justified power to force those within its jurisdiction to consume its services, to obey its laws. What (if anything) exactly gives this enterprise this justified power? Normativity has now entered the picture, not because $I$ have introduced it, but because those who claim the Constitution as their "authority" for their actions also claim the justified power to coerce others to accept their commands. It is then perfectly appropriate to ask whether this normative claim is warranted or not. And this is, of course, a normative inquiry.

For example, when A.T.F. agents in military-style uniforms and armed with genuine automatic assault weapons 23 invaded the property of the Branch Davidians in Waco they implicitly made a normative claim that they were acting in a justified manner. It was their claim to be exercising a justified power, as opposed to anyone's decision to write an article about this claim, that gave rise to the need to address the normative question of legitimacy. That their acts may have been authorized by the Constitution does not settle the problem of legitimacy, it raises it. For the problem of legitimacy that I am discussing here applies to the Constitution itself. 24

But the normative inquiry does not end there. For those who claim to be empowered by the Constitution make a further claim as well. They claim that you and I are morally obliged (at least prima facie) to obey their commands. It is claimed (and commonly thought) that David Koresh and his followers were not only legally obliged to lay down their weapons in the face of these "agents" of the "duly constituted authority" acting "under color of law." They were morally obliged as well. Their failure to obey is claimed to have been wrongful as well as illegal. Had these invaders been anyone other than the "public officials" they

23. As distinct from the semi-automatic so-called "assault weapons" recently prohibited by the Congress.

24. To see why authority by itself is not enough, suppose that you are my agent and I authorize you to take someone's car by force if needed. When the car owner resists, you tell her that I have authorized you to take the car, which is true. She may then appropriately ask what gives me the right or power to authorize such a thing. Why should she care what I have or have not authorized? In addition to showing that your acts were authorized, you must also show that either you or I had the justified power to take the car by force and that she had a duty to refrain from interfering. The A.T.F. agents' attempt to justify their conduct solely by appealing to the authority of the Constitution is like appealing to the authority that I granted my agent. It leaves out the normative dimension of the claim being made. Of course, had their actions been unauthorized, then the problem of legitimacy raised by the Constitution would not be implicated. They would have been acting illegally as well as, perhaps, unjustly. 
called themselves, the residents of the compound would surely have been justified in defending themselves against such heavily armed marauders. But solely by virtue of the A.T.F. agents' claim of legal authority, the normative conclusion is said to be completely reversed. Now those who might otherwise have been viewed as defending themselves from aggression are considered murderers rather than innocent victims of a potentially deadly assault (or would be if they had survived the final conflagration).

So the existence of the parchment under glass we call the Constitution raises a two-fold normative problem: what (if anything) gives the persons who claim the authority of its organizational scheme the justified power to issue commands to the rest of us? And what (if anything) creates in the rest of us a moral duty to obey these commands? Perhaps these are two aspects of the same question. No matter. The fact is that these questions are not ordinarily addressed because most people simply assume that both the command-issuing power and the moral duty of obedience exists, and so they are not much interested in why. Why struggle with a question to which one already knows the answer?25

Still, the normative question is not so easily avoided. As Steve Macedo has observed, "[a]t the most basic level, moral principles play an inescapable role in constitutional interpretation, and that is because the choice of an interpretive strategy, indeed, the very question of how we ought to construe the meaning of "law," are themselves moral questions."26 In other words, whether one is an "originalist," a "textualist," or an adherent to the "living constitution" school of constitutional interpretation depends on at least an implicit answer to the problem of legitimacy. Originalists, textualists, et al. are implicitly making some sort of claim about the origin of constitutional legitimacy and the individual's duty of obedience. Normativity cannot be avoided because it is omnipresent. You cannot engage in discourse about the Constitution and its proper interpretation without making implicit claims about legitimacy.

I suggest that to address the question of legitimacy of the Constitution, we must begin by asking the point or function of

25. Although most constitutional scholars ignore this question, at least one philosopher has both considered the problem and addressed it in much the same way as I advocate here. See Jeffrey Reiman, The Constitution, Rights, and the Conditions of Legitimacy, in Alan S. Rosenbaum, ed., Constitutionalism. The Philosophical Dimension 127 (Greenwood Press, 1988).

26. Stephen Macedo, Morality and the Constitution: Toward a Synthesis for "Earthbound" Interpreters, 61 U. Cin. L. Rev. 29, 30 (1992). 
the enterprise it regulates. 27 Of course, the enterprise may very well have many more than one point but I shall focus on one particular function that I think even the most minimal of statists would concede to be central and which directly grows out of the previous discussion: it is an enterprise that is supposed to produce commands that create in the citizenry a moral duty of obedience. 28

Some philosophers of law might rightly deny that the commands issued by the duly constituted authority necessarily create a duty of obedience. Robin West, for example, has argued that, "if we wish to make our laws just, we must first see that many of our laws are unjust, and if we are to understand that simple truth, we must understand that the legality of those norms implies nothing about their justice." 29 Taken as a conceptual claim, I entirely agree with this statement, although I think it is highly misleading. True, many of our laws are unjust. And it is also true that the legality simpliciter of those norms tells us nothing about their justice. If both of these claims are true, then it is further true that the mere fact that an edict is legal tells us nothing about whether there is moral duty to obey its dictates. 30

But despite its validity, this syllogism is deeply problematic. For it elides the fact that people almost uniformly believe that because a norm is legal, it creates at least a prima facie duty of obedience. So, to return to the example of Waco, most people (outside of Texas) condemned the Branch Davidians without ever asking exactly which legal "norm" it was that they had allegedly violated. Nor was there any interest in asking whether the Branch Davidians were actually guilty of violating whatever rule was being enforced. These questions were not asked because for most people the mere fact that a legal norm was being enforced by the duly-constituted authorities was enough for them to conclude that the Branch Davidians had a moral duty to comply with the orders of the A.T.F.

27. Cf. Reiman, The Constitution, Rights, and the Conditions of Legitimacy at 132 (cited in note 25) ("[I]t is not possible to choose .. . [the appropriate method of constitutional interpretation] without having some theory of what the Constitution is, what its point is, what its source of obligatoriness is, and so on.") (emphasis in the original).

28. See id. at 133 ("Legitimate power means (at least) power with which we are morally obliged to comply.").

29. Robin West, Natural Law Ambiguities, 25 Conn. L. Rev. 831, 831 (1992) (emphasis in original).

30. It is possible to argue that people also have a moral duty to obey unjust laws for reasons of, say, the need to maintain social order. Indeed, Aquinas himself so argued in the passage immediately following that quoted in note 21. Although I do not reject such a claim, it is, needless to say, in need of substantial elaboration and defense. 
Professor West might respond that this is the very problem she is addressing. People should be far more skeptical about the legitimacy of legal norms, she might well argue, and only by insisting on the strict separation of law and morals are we likely to induce this sort of skepticism. While I agree that people should be far more skeptical than they are, I reject a radical schism between law and morals as the most efficacious path to this mind set. And I am not sure that complete skepticism is what Professor West desires. Do we want every citizen to evaluate entirely independently every law to assess its justice? Maybe we do. Do we want every citizen to obey only those laws which he or she concludes is just? Probably not. Perhaps this is why most people go with the legal flow and condemn the lawbreaker without themselves scrutinizing the law that was violated.

If, however, we want people to feel obliged to adhere even to some laws the justice of which they may doubt, then it cannot be the case that "the legality of those norms implies nothing about their justice." Or perhaps more accurately, although in some legal systems this statement may be completely accurate, we cannot be satisfied with such a value-neutral process of legality in a society in which "law" is such a value-laden term. For unless we demand a process in which the legality of a norm does imply something about its justice we will have failed to achieve the objective of having a system of norm creation, dissemination, and enforcement that does create a prima facie moral duty of obedience in the citizenry-where, in short, the widespread perception of legitimacy is warranted. And lawmakers in a society that believes that legal norms are binding in conscience will get a powerful "benefit of the doubt" or "halo-effect" to which they are not entitled.

To avoid confusion, it is important to stress once again that, while the term law is so value-laden because people generally believe that validly enacted laws bind in conscience, the conception of legitimacy I am employing is not to be equated with the public's belief or perception that enactments claimed to be laws are likely to be just. Instead, I am taking this belief as given and asking whether this perception is warranted given the constitutional processes that produced the enactment, just as we might ask whether the public's belief or perception that a particular law is valid is warranted or not. Is the lawmaking process such as to warrant a belief that it is likely to be delivering what it is promising to deliver: laws that bind in conscience? Thus the concept of legitimacy is not to be confused with the perception of legitimacy. 
The public's perception of legitimacy may very well be wrong. Ensuring that it is correct is the problem of legitimacy at issue here.

We can reach this same conclusion from a somewhat different direction by distinguishing between "producers" and "consumers" of legal commands. In our (and I would contend every) legal culture, those who produce laws implicitly claim that citizens have a duty to obey lawful commands. And in most cultures, the consumers of the product of the legal system accept this claim of the producers. To the extent that this claim is both made and accepted, there is then an implied warranty of merchantability that accompanies every lawful command. Just as the grocer selling sausages implicitly warrants that the sausages are wholesome and fit for human consumption, ${ }^{31}$ the purveyors of lawful commands implicitly warrant that their commands are just (or, at a minimum, are not unjust ${ }^{32}$ ), and these commands, by virtue of their justice, create in the citizen a duty of obedience.

This implied warranty of merchantability could be disclaimed by, for example, explicitly stating that there is no moral obligation to obey a particular enactment. The fact that this disclaimer is never issued, however, conveys to the public the intent to warranty the merchantability of lawful commands. It may be true, as Otto von Bismarck is reported to have said, that it is better not to know how either sausages or laws are made. If, however, we are to eat the one and obey the other then someone better inquire as to the adequacy of the respective production processes. If each consumer has a moral duty to obey lawful commands without questioning each and every one (as people generally believe and as lawmakers want them to believe), then those who produce the laws and who implicitly warrant their merchantability have a corresponding duty to put in place adequate quality-control mechanisms to ensure the wholesome of the commands they purvey. ${ }^{33}$

31. See U.C.C. \& 2-314(1) (American Law Institute, 1990):

Unless excluded or modified ...., a warranty that the goods shall be merchantable is implied in a contract for their sale if the seller is a merchant with respect to goods of that kind. Under this section the serving for value of food or drink to be consumed either on the premises or elsewhere is a sale.

32. I have in mind the many laws that are entirely conventional in nature, such as traffic regulations, and not in themselves requirements of justice. Such laws are conventional in the sense that, although there may be many different ways to accomplish a particular end, some way must authoritatively be settled upon. Still, it is appropriate to ask of any particular convention whether it is unjust.

33. Cf. Reiman, The Constitution, Rights, and the Conditions of Legitimacy at 131 (cited in note 25): "[L]egitimate government is not simply one that keeps to a pre-established recipe for legitimacy but one that has built into it an institutional mechanism for 
This part of my analysis can be summarized as follows: If lawmakers claim that people have a prima facie moral duty to obey legal norms, and if it is desirable that people accord laws a presumption of legitimacy (albeit within limits), then the system which produces these legal norms must have the requisite institutional quality to justify this presumption. To promulgate enactments without taking steps to ensure their justice and calling these enactments "laws" knowing that orders so labeled benefit from the presumption of legitimacy, is to promise one thing while delivering another. It is, in short, constitutional bait-and-switch. If the term "lawful" or "law" is to carry the normative implication that there is a moral duty to obey, then the requisite binding quality must go in before the name "law" goes on.

\section{NATURAL RIGHTS AND CONSTITUTIONAL INTERPRETATION}

My principal objective in this article is to advance the argument of the preceding Part - that for constitutional processes to be legitimate, they must include procedures to assure that lawful commands are justified and of such a nature as to bind in conscience. In this Part, I suggest what quality enactments must have to bind in conscience and how this quality should influence our interpretation of the Constitution. Here I share the framers' belief that enactments should not violate the inherent or natural rights of those to whom it is directed. That this was their beliefand that this belief is reflected in the words of the Ninth Amendment-is conceded even by those who would contest the appropriateness of judicial intervention to ensure that laws have this rights-respecting quality. ${ }^{34}$ In addition, I contend that an assurance that a law has not infringed the enumerated and unenumer-

continually reflecting on the conditions of its legitimacy and for effectively translating the results of that reflection into law."

34. For example, Thomas McAffee, Philip Hamburger, and Michael McConnell all agree that the framers were very much concerned with natural rights. See, e.g., McAffee, 61 U. Cin. L. Rev. at 119 n.41 (cited in note 15) ([T]here is reason to think that the founders sought to establish a fairly particular vision of natural law and natural rights rather then an open-ended methodology in which subsequent decision-makers would feel free to reject their decisions as to the basic content of natural rights."); Hamburger, 102 Yale L.J. at 915 (cited in note 15) ("[L]arge numbers of Americans spoke about government, liberty and constitutional law on the basis of some shared assumptions about natural rights and the state of nature."); Michael W. McConnell, $A$ Moral Realist Defense of Constitutional Democracy, 64 Chi-Kent L. Rev. 89, 99 (1989) ("The founders of the United States were believers in natural right .... The Constitution was framed in accordance with the people's understanding of natural right; we know this from the preamble's statement of intentions."). Rather, these writers question whether the founders contemplated or intended the legal enforceability or judicial protection of these rights. 
ated rights retained by the people is a necessary (though perhaps not a sufficient) condition of the legitimacy of the lawmaking process.

What are these natural rights and why does legitimacy require that they be respected? Elsewhere, speaking not for the framers but for myself, I have offered the following definition: natural rights are the set of concepts that

define the moral space within which persons must be free to make their own choices and live their own lives. They are rights insofar as they entail enforceable claims on other persons (including those who call themselves "government offcials"). And they are natural insofar as their necessity depends upon the (contingent) nature of persons and the social and physical world in which persons reside. 35

In sum, "the pre-existent rights of nature," in Madison's words, are those rights that "are essential to secure the liberty of the people." 36 A respect for these rights is as essential to enabling diverse persons to pursue happiness while living in society with others as a respect for fundamental principles of engineering is essential to building a bridge to span a chasm. ${ }^{37}$

35. Randy E. Barnett, The Intersection of Natural Rights and Positive Constitutional Law, 25 Conn. L. Rev. 853, 862 (1993).

36. J. Gales and W. Seaton, eds., 1 The Debates and Proceedings in the Congress of the United States 454 (1834) (statement of James Madison) (emphasis added). In the passage from which these phrases are taken, Madison is arguing that the right of trial by jury enumerated in the proposed amendments, though a "positive right," is as essential to secure the liberty of the people as any natural right.

37. Although I do not claim that all Americans in the founding generation shared this (or any) conception of natural rights, it is clear that some did. For example, Pastor Elizur Goodrich (1734-1797) made a functional argument of this sort in an "election sermon" he delivered to the governor and general assembly of Connecticut on the eve of the Constitutional Convention:

The principles of society are the laws, which Almighty God has established in the moral world, and made necessary to be observed by mankind; in order to promote their true happiness, in their transactions and intercourse. These laws may be considered as principles, in respect of their fixedness and operation; and as maxims, since by the knowledge of them, we discover these rules of conduct, which direct mankind to the highest perfection, and supreme happiness of their nature. They are as fixed and unchangeable as the laws which operate in the natural world.

Human art in order to produce certain effects, must conform to the principles and laws, which the Almighty Creator has established in the natural world. He who neglects the cultivation of his field, and the proper time of sowing, may not expect a harvest. He, who would assist mankind in raising weights, and overcoming obstacles, depends on certain rules, derived from the knowledge of mechanical principles applied to the construction of machines, in order to give the most useful effect to the smallest force: And every builder should well understand the best position of firmness and strength, when he is about to erect an edifice. For he, who attempts these things, on other principles, than those of nature, attempts to make a new world; and his aim will prove absurd and his labour 
Natural rights must be distinguished from "natural law" (or what some refer to as natural right38). Each of these concepts addresses different problems. Natural law or right is a method of assessing the legitimacy of individual conduct. This method is used to stipulate, for example, that persons should live their lives in certain ways and not in others. ${ }^{39}$ The concept of natural rights, in contrast, while sharing a common intellectual ancestry and

lost. No more can mankind be conducted to happiness; or civil societies united, and enjoy peace and prosperity, without observing the moral principles and connections, which the Almighty Creator has established for the government of the moral world.

Elizur Goodrich, The Principles of Civil Union and Happiness Considered and Recommended, in Ellis Sandoz, ed., Political Sermons of the American Founding: 1730-1805 91415 (Liberty Press, 1991) (emphasis added).

Lest this quote reinforce a modern misconception about traditional natural rights theory, note that although Goodrich identifies God as the original source of the laws that govern in the moral world, so too does he identify God as the source of the laws that govern agriculture and engineering. With both types of principles and laws, once established by a divine power they become part of the world in which we find ourselves and are discovered by human reason. Thus, today one can no more disparage natural rights because Eighteenth Century thinkers attributed their origin to a divine power than one can disparage the laws of physics because Eighteenth Century scientists believed that such laws were also established by God. Whatever the source of these moral laws, Goodrich's argument is that they must be respected if we are to achieve the end of happiness, peace, and prosperity. This view of moral laws assumes, of course, that happiness, peace, and prosperity are appropriate ends. Should anyone question this assumption, additional arguments will need to be presented.

38. See, e.g., McConnell, 64 Chi. Kent L. Rev. at 89 (cited in note 34) (consistently referring to natural right as opposed to natural rights). But cf. Masugi, 9 Pol. Communication at $245 \mathrm{n} .5$ (cited in note 10) ("In accordance with the rough practice of the American Founders, I use natural rights and natural law interchangeably. Natural right is the more comprehensive term."). Although I agree that the founders were far from uniform in their usage, the political writings I have read seem almost invariably to use the language of natural rights as opposed either to natural law or natural right. See, e.g., Roger Sherman's Draft of the Bill of Rights, in 1 Randy E. Barnett, ed., The Rights Retained by the People: The History and Meaning of the Ninth Amendment 1 (George Mason U. Press, 1989) ("The people have certain natural rights which are retained by them when they enter into Society. . . ."); Madison's Notes for Amendments Speech, 1789, in id. at 64 ("Contents of Bill of Rhts.... 3. natural rights retained as speach [sic]."). Indeed, use by the founders of the term natural right would have been quite aberrational.

More importantly, Masugi's use of natural right as the more comprehensive term elides the appropriate distinction between the two modes of thought. It also seems to be at odds with the usage of contemporary writers who systematically prefer the term natural right to natural rights and in contexts that suggest that they really mean natural law. Russell Hittenger, for example, uses the term in the context of natural law, as opposed to natural rights, and attributes it to Aquinas. See Hittenger, 55 Rev. of Politics at 5 (cited in note 12) (referring to "the only article of the Summa exclusively devoted to the issue of natural right (ius naturale)"). In sum, the recent tendency to supplant the term natural rights with that of natural right has only compounded the normal academic confusion of the concept of natural law with that of natural rights. This terminological development seems to be associated with scholars who have been influenced by the writings of Leo Strauss.

39. See, e.g., Henry B. Veatch, For an Ontology of Morals: A Critique of Contemporary Ethical Theory (Northwestern U. Press, 1971). 
methodology with natural law, addresses a quite different problem. It asks, not what the good life is for each person and how each person should act, but what moral "space" or "jurisdiction" each person requires in order to pursue the good life in society with others.

In sum, whereas natural law assesses the propriety or ethics of individual conduct, natural rights assesses the propriety or justice of restrictions imposed on individual conduct.40 Of course, the same conduct-murder, for example-might be thought to violate natural law because it is "bad" (persons should not kill others except in self-defense), and because it is unjust (persons have a right not to be killed except in self-defense). But the reasons why actions are bad are not always the same as why they are unjust, and it has long been recognized that many actions that are bad are not unjust, in the sense that they violate the rights of others. 41 And on rare occasion, it may not be bad to act unjustly-as for example when, in an emergency, one takes property that rightfully belongs to another to save one's life.

Contrary to the claims of critics of liberalism, then, natural rights are not conceived of as "presocial"; 42 nor do they assume "atomistic" individuals. Rather, the term natural rights refers to those rights that are inescapably needed precisely to protect individuals and associations from the power of others-including the power of the stronger, of groups, and of the State-when and only when persons are deeply enmeshed in a social context. Such rights would be entirely unnecessary if individuals were not in society with each other, or if the actions of some persons did not adversely affect the welfare of others. Moreover, a constitutional commitment to protecting natural rights (as opposed to enacting natural law) does not entail any general mandate to legislate mo-

40. I do not claim that everyone, or even most people, use all these terms in precisely this way. I claim only that natural law thinking is distinguishable from natural rights thinking and that this terminology best describes the difference between them. Moreover, running these two modes of thought together leads to serious confusion.

41. For example, natural law theorist Thomas Aquinas, writing centuries before natural rights developed as a separate methodology, argued:

Now human law is framed for a number of human beings, the majority of which are not perfect in virtue. Therefore human laws do not forbid all vices, from which the virtuous abstain, but only the more grievous vices, from which it is possible for the majority to abstain, and chiefly those that are to the hurt of others, without the prohibition of which human society could not be maintained; thus human law prohibits murder, theft and the like.

Aquinas, Summa Theologica at 232 (cited in note 21) (emphasis added).

42. These rights are, however, conceived of analytically as pre-governmental. Perhaps the charge that liberals conceive of rights as presocial is persistent because some critics of liberalism are so committed to statism that they equate government with society. 
rality. Rather than imposing moral duties on persons to live their lives in certain ways, natural rights protect persons from the State and from each other. 43

Both the claim that such background rights are necessary and their exact contours are, of course, contestable and contested 44 and I shall not argue the matter here. 45 That the founding generation believed in their necessity is without question, however, and that they viewed their protection as the highest end of the Constitution is also generally conceded. Nonetheless, the relevance of this belief is open to question. Perhaps, as some have argued, the framers of the Constitution did not believe that such rights merited judicial protection unless they were expressly included in the constitutional text. I have attempted to answer this question elsewhere 46 and this is not the place to rehearse my arguments and those of others who take the same position, ${ }^{47}$ nor the arguments of our worthy opponents. 48 To date this has been one of the most hotly debated issues surrounding the Ninth Amendment.

43. For this reason, the constitutional protection of these rights may include both a "negative" duty of government to refrain from infringing these rights and a "positive" duty upon government to protect the rights of its citizens from infringement by others. See Steven J. Heyman, The First Duty of Government: Protection, Liberty and the Fourteenth Amendment, 41 Duke L.J. 507, 510 (1991) ("[T]he classical conception of liberty was not merely negative, but had a crucial positive dimension-the protection of individual rights under law."). Of course, to claim that a constitution imposes positive duties on government is not to concede that it imposes positive duties on the citizenry. In the main, the Constitution "constitutes" the government of the United States and regulates its powers; it does not purport to regulate the rights of the people.

44. Some eschew the term natural rights because of metaphysical claims they associate with it; they prefer instead the term "moral right" or "human right." Adopting this terminology does not affect the analysis presented here, provided that (1) a moral right is considered to be an enforceable claim, or what the classical natural rights theories called a "perfect" right as opposed to "imperfect" moral rights which are unenforceable; and (2) a moral right is not the equivalent of a legal right, but is a concept used to evaluate the justice of legal rights.

45. I have provided the beginnings of a functional account of the core rights traditionally recognized by liberalism-several property and freedom of contract-in Randy E. Barnett, The Function of Several Property and Freedom of Contract, 9 Soc. Phil. \& Policy 62 (1992). There I argue that these concepts are essential because they address the pervasive social problems of knowledge, interest, and power.

46. See Randy E. Barnett, Introduction: Implementing the Ninth Amendment in Barnett, ed., 2 Rights Retained by the People at 1 (cited in note 6); and Randy E. Barnett, Reconceiving the Ninth Amendment, 74 Corn. L. Rev. 1 (1988). A revised version of this article appears as Introduction: James Madison's Ninth Amendment, in Barnett, ed., 1 Rights Retained by the People at 1 (cited in note 38).

47. See, e.g., Heyman, 16 S.I.U. L.J. 327 (cited in note 16); Massey, 61 U. Cin. L. Rev. 49 (cited in note 16); Mayer, 16 S.I.U. L.J. 313 (cited in note 16); Morton, 22 Seton Hall L. Rev. 709 (cited in note 16); Sherry, 61 U. Cin. L. Rev. 171 (cited in note 1); Sherry, 54 U. Chi. L. Rev. 1127 (cited in note 16).

48. See the authors cited supra note 15 . 
Instead, I wish to use the preceding analysis of legitimacy to address a question that has long surrounded any discussion of the framers' intent: Assuming that the founding generation did believe that legislation that violated natural rights was beyond the powers of government and therefore void, why are we who are alive today bound by their beliefs, particularly if we now reject the concept of natural rights as outmoded and even incomprehensible?

According to the approach presented here we, as citizens, are not bound by the framer's intentions. Rather, I am claiming (a) that the framers wrote a constitution, the text of which some persons alive today purport to be governed by when they issue supposedly binding commands to us; (b) that we are bound in conscience to obey these commands only if the lawmaking processes established and regulated by this text provide assurance that our rights have not been violated; (c) that if the Constitution provides effective protection of rights, then the lawful commands of constitutional authorities may be justified and binding and, if not, then we obey solely to avoid punishment.

For these reasons, the fact that the text of the Constitution includes the words, "[t]he enumeration in this Constitution, of certain rights, shall not be construed to deny or disparage others retained by the people," 49 is significant. For the Ninth Amendment, along with the Privileges or Immunities Clause of the Fourteenth, 50 supports the view that, as a descriptive matter, the assessment of constitutional validity - by the judiciary or anyone else-established by the text of the Constitution did (and until it is amended still does) include a constitutional solicitude for natural rights. And if this interpretation or description of the text is accepted as correct, then the Constitution may, as a normative matter, be legitimate. If it is incorrect, then the legitimacy of the Constitution is called into question.

It is, then, necessary to take a stand one way or the other as to the best interpretation of the Ninth Amendment and the Privileges or Immunities Clause, just as it necessary to take a stand on the best interpretation of the First Amendment, the Necessary and Proper Clause, and all other relevant portions of the Constitution. It is simply inadequate to point to the disagreements that exist and then blithely ignore the Constitution on the grounds

49. U.S. Const. Amend. IX.

50. See U.S. Const. Amend. XIV, \& 2 ("No State shall make or enforce any law which shall abridge the privileges or immunities of citizens of the United States. ..."). Obviously the framers of this amendment were able, along with Aquinas, to distinguish conceptually between a validly enacted and a binding and enforceable "law." 
that competing interpretations have been offered. A proper interpretation of the Constitution as a whole requires a proper interpretation of these passages as well as all the others. There is no escape, therefore, for anyone interpreting the Constitutionwhether the interpreter be a judge or a law professor-to confront the conflicting arguments and evidence and decide which is the most convincing interpretation of the rights "retained by the people" and the Constitution's injunction that they be neither denied no disparaged.

To put the matter starkly, those who argue, first, that the framers intentions matter when interpreting the Constitution and, second, that the framers did not intend that all branches of government strive to protect the unenumerated rights retained by the people, should hope that they are wrong on at least one count. For, if they are correct both that courts are bound by the original meaning of the constitutional text and that this text does not provide any protection of unenumerated rights, then they may have won the constitutional battle, yet lost the legitimacy war. They would have succeeded only in proving that the constitution now in effect does not provide what it must provide to make laws that are justified and bind in conscience. For if those who produce and inspect legislation are not bound to respect the rights retained by the people, then the people are not bound to respect their laws.

Fortunately, they are wrong. The argument that the Constitution as amended established a regime of democratic majoritarianism fettered only by those rights which were enumerated is belied by both its text and history - not to mention a goodly part of our constitutional jurisprudence. That we should resolve our historical and textual doubts in favor of protecting unenumerated rights is bolstered by the moral argument that even democratic majorities must justify their forcible impositions on minorities. As Jeffrey Reiman has argued,

there is nothing inherently legitimating about the electoral process. If anything, the electoral process is the problem, not the solution.... [T] he policies that emerge from the electoral process will be imposed on the dissenting minority against its wishes. And then, rather than answering the question of legitimacy, this will raise the question with respect to those dissenters. Why are the exercises of power approved by the majority against the wishes of (and potentially prohibiting the desired actions of) the minority obligatory with respect to the minor- 
ity? Why are such exercises of power not simply a matter of majority tyrannizing the minority?51

Our choice among interpretations as well as interpretive methods is, then, a normative one. The "best" interpretation of the U.S. Constitution is one that takes the natural or background rights of persons into account when evaluating the legitimacy of any governmental regulation of a person's rightful exercise of his or her liberty. For unless we do, the enterprise which the Constitution establishes and regulates will have failed in its essential function of providing justified laws that bind in conscience.

One question remains. If we generally believe in a core of liberty or "retained" rights that is to be protected from government intrusion (as the furor over Robert Bork's dismissal of the Ninth Amendment suggests we do), if this belief is well founded (as I think it is), and if the constitutional text can fairly be read as justifying scrutiny of legislation to see if it has infringed these retained rights (as I think it can), then: Do laws that regulate a person's conduct within this protected domain bind in conscience those whose liberty is being regulated? There are two approaches one can take to this question.

First, one could take the strong libertarian position that such rights may never be regulated by anyone, including the government, and that any enactment that does so is unjust and void. Although this view may very well be correct as a matter of moral and political theory, it is not the view embodied in the text of the Constitution. For if natural rights are to be absolutely protected from any regulation, then no governmental action would withstand scrutiny. If such rights merit absolute protection (as well they may), this constitution neither promises nor provides such protection. If that fact deprives the Constitution of all legitimacy, then so be it. On the other hand, it may be that legitimacy is a relative concept, so that the Constitution's less than absolute protection of natural rights means that it is superior to many alternative political arrangements, but inferior to others.

51. Reiman, The Constitution, Rights, and the Conditions of Legitimacy at 134 (cited in note 25). As he elaborates:

These questions not only point up the error of taking electoral accountability as an independent source of legitimacy, they also suggest that it is mistaken to think of electoral accountability and constitutional provisions as alternative sources of legitimacy. Rather, the Constitution with its provisions limiting the majority's ability to exercise power is the answer to the question of why decisions voted by a majority are binding on the minority who disagree. Id. 
Second, one may take the view that (for better or worse) the Constitution provides less than absolute protection of the background natural rights retained by the people. So, for example, the exercise of such rights may be regulated by the general government if it is exercising a delegated power and if the exercise of this power is both necessary and proper.52 Although according to this view, the Constitution does contemplate the regulation of these background rights under these conditions, 53 the existence of these rights even when properly regulated remains significant in two respects: first, the fact that governmental actions restrict the exercise of a person's rights places the burden of justification on that branch of government which seeks to act in this way. Second, the fact that the rights retained by the people are inalienable (as I contend ${ }^{54}$ ) means that, even when their regulation is shown to be authorized, necessary, and proper, persons still retain their rights and may insist that a particular type of regulation cease when it has ceased to be necessary. In sum, rights do not evaporate just because they have once been regulated. Only this second conception of natural rights permits us to reconcile the protection of the background rights retained by the people, with the government powers, albeit limited, that the Constitution acknowledges. 55

\section{TAKING NATURAL RIGHTS INTO ACCOUNT: THE PRESUMPTION OF LIBERTY}

So my answer to the second of Suzanna Sherry's questions is that we most certainly want to reconcile our natural rights past with our textualist present. But how? To some extent, I have suggested my answer to this question as well. I have suggested

52. For a discussion of the distinct meanings originally attached by the founding generation to the terms "necessary" and "proper," see Gary Lawson and Patricia B. Granger, The "Proper" Scope of Federal Power: A Jurisdictional Interpretation of the Sweeping Clause, 43 Duke L.J. 267 (1993).

53. As explained below, according to this conception of the Constitution, the regulation of natural rights is to be distinguished from their infringement. A purely libertarian conception of natural rights might well find that the Constitution also sanctions the latter. For example, the Sixteenth Amendment permits the taxation of income, and the Fifth Amendment permits takings of private property for public use when "just compensation" is made.

54. For several reasons why some rights are inalienable, see Randy E. Barnett, Contract Remedies and Inalienable Rights, 4 Soc. Phil. \& Policy 179 (1986).

55. See Henry B. Veatch, Human Rights: Fact or Fancy? at 202-208 (La. State U. Press, 1985) (defending from a natural law perspective a conception of inalienablerather than absolute - natural rights that are justified because they afford the necessary conditions for the living of a good life, and that must be protected by an independent judiciary lest either the public authorities or the private individual be made a judge in his own cause.) 
that the existence of inalienable natural rights that exist independently of governmental fiat means that those persons who act "under color of law" have a duty to respect these rights, and to show that any regulation of them is both necessary and proper. Having made this showing with respect to a particular enactment does not cause the right that has been regulated to be lost. The inalienability of rights means that when an enactment ceases to be necessary and proper, it no longer binds the conscience of the citizenry.

This approach is what $\mathrm{I}$ have elsewhere referred to as the "presumptive method" 56 of protecting constitutional rights and it is based on what I have called the "presumption of liberty." 57 This presumptive method enables courts to protect natural rights without them ever having to use the term or compile a comprehensive list of these rights. The presumption of liberty can only be operational, however, if it is enforceable. It is woefully inadequate to insist that legislatures or executive branch officials may be the judge in their own cases when their actions are alleged to infringe upon the rightful liberty of a citizen. The whole purpose of natural rights in this context is to protect persons from legislative or executive abuses. Unless these rights are protected by relatively "independent tribunals of justice," 58 they are virtually

56. See Barnett, Introduction: Implementing the Ninth Amendment in Barnett, ed., 2 Rights Retained by the People at 10-46 (cited in note 16) (describing and defending the adoption of a "presumption of liberty"). Elsewhere, I have identified two other methods of protecting unenumerated rights. See Barnett, 74 Corn. L. Rev. at 30-38 (cited in note 46) (distinguishing between the originalist, constructivist, and presumptive methods of interpreting unenumerated rights). The "originalist method" seeks to identify the founding generation's conception of natural rights by surveying the same historical materials in which originalists seek evidence of the original meaning of other constitutional provisions. See e.g., Jeff Rosen, Was the Flag Burning Amendment Unconstitutional?, 100 Yale L.J. 1073, 1074-81 (1991) (enumerating the framers' conception of natural rights); Donald S. Lutz, The States and the U.S. Bill of Rights, 16 S.I.U. L.J. 251 (1992) (comparing state ratification convention proposals and state bills of rights with Madison's proposal to Congress and the enacted Bill of Rights). The "constructivist method" attempts to construct a theory of the rights retained by the people and then use this theory to ground particular rights. The Supreme Court's construction of the "right of privacy" from various textual passages of the Constitution is one way of employing the constructive method. See, e.g., Griswold v. Connecticut, 381 U.S. 479 (1965).

57. This and the next three paragraphs summarize the analysis I have presented at greater length elsewhere, after which I describe some additional features of this approach.

58. The phrase is taken from Madison's speech to the first House of Representatives in defense of his proposed amendments to the Constitution: "If they are incorporated into the constitution, independent tribunals of justice will consider themselves in a peculiar manner the guardians of these rights ...."1 The Debates and Proceedings in the Congress of the United States at 457 (cited in note 36) (statement of James Madison), reprinted in Barnett, ed., 1 Rights Retained by the People at 51 (cited in note 38). 
worthless.59 Of course, if legislatures do take pains to regulate the rights of citizens only when it is necessary and proper to do so, we can expect them to be able to justify their actions. Regrettably, our experience with legislatures has not been so utopian. For this reason, meaningful "scrutiny" by an impartial magistrate of legislative and executive branch actions that impinge upon the liberty of individuals and associations is required.

According to the current thinking, there can be different degrees of scrutiny - so-called rational basis scrutiny, strict scrutiny and intermediate scrutiny-and there exists a multitude of formulations of each. To the extent that every statute can withstand rational basis scrutiny and no statute can pass strict scrutiny, this distinction is disingenuous. To adopt one type of scrutiny is to eliminate all review; to adopt the other is to eliminate all legislation affecting any exercise of liberty. I have therefore deliberately chosen the phrase meaningful scrutiny to denote a real examination of legislation (or executive actions) to determine whether it is really necessary to restrict liberty in order to accomplish a legitimate governmental end, and whether the type of means chosen to effectuate this end is proper-that is within the appropriate powers of government. The former question is instrumental; the latter may entail an examination of the background rights of the people.

So, for example, the power to conscript citizens into the military is not listed among the enumerated powers of Congress. If valid, conscription must be justified under the necessary and proper clause as both necessary and proper to facilitate Congress' power to raise and support an army. Is it really necessary to conscript citizens into the military to provide a national defense? Is conscription a proper exercise of governmental power? Similarly, the enumerated congressional power to establish a post office does not include the power to confer a monopoly on the Post Office so established.60 Is such a monopoly really necessary for mail service to be provided? Is the grant of monopolywhich coercively puts competitors out of business-a proper ex-

59. Cf. Reiman, The Constitution, Rights, and the Conditions of Legitimacy, at 144 (cited in note 25).

On my view, the Court's decisions must be legally binding precisely because they

are decisions about the conditions of legitimate governance by the other branches, conditions whose determinations cannot be left up to those branches. Unless the Court's decisions are legally binding, a necessary condition of legitimacy, namely, a built-in mechanism for not only monitoring but effectively correcting the conditions of legitimacy, is lacking.

60. The Articles of Confederation did expressly confer such a power upon Congress. See Art. of Confederation, Art. IX (1777). 
ercise of governmental power?61 Meaningful scrutiny does not presuppose any particular answer to such questions. It simply means that when a person's rightful liberty is restricted by government, that person may challenge the restriction and, if challenged, the burden is placed upon the government to justify the restriction as a necessary and proper regulation of liberty. This is not to exalt the judiciary, but the citizen. In Charles Black's words, "[i]f we are committed to anything, it is the idea of "liberty.' If that commitment doesn't really refer to anything except a good inner feeling, we ought to shut up about it." 62

According to this approach and contrary to the view prevailing today, the power to regulate-i.e., make regular-the exercise of liberty is not the same as the power to prohibit.63 If the presumption of liberty did nothing other than prevent the complete prohibition of rightful conduct, it would be an important departure from the current constitutional approach.64 Still, no

61. The ratification conventions of four states-Massachusetts, New Hampshire, New York, and North Carolina-formally requested that prohibitions on granting monopolies be included in the Bill of Rights. See Appendix B: Amendments to the United States Constitution Proposed by State Ratification Convention, in Barnett, 1 Rights Retained by the People, at 354, 355, 360, 369 (cited in note 38). New York's proposal read: "That the Congress do not grant monopolies, or erect any company with exclusive advantages of commerce." Id. at 360 . In his speech to the House concerning the constitutionality of the first national bank, Madison condemned the proposal, in part, on the ground that "[i]t involves a monopoly, which affects the equal rights of every citizen." Appendix A: Madison's Speech on the Constitutionality of the Bank of the United States, in Barnett, 2 Rights Retained by the People, at 423 (cited in note 6).

62. Charles L. Black, Jr., On Reading and Using the Ninth Amendment, in Barnett, 1 Rights Retained by the People at 345 (cited in note 38).

63. The distinction between regulation and prohibition is not always easy to maintain in practice. Any regulation of liberty necessarily prohibits its exercise in ways that are contrary to the regulation. So, for example, time, place, and manner regulations of speech in public spaces necessarily prohibit speech that conflicts with these regulations. Still, a regulation of speech should not be intended to effectuate a prohibition, and at the extremes this distinction may be quite clear. Thus, it is not difficult to distinguish the regulation of the liberty to use intoxicating drugs from a prohibition of such use. For a discussion of how the existence of "hard cases" of constitutional interpretation does not preclude the existence of "easy cases," see Frederick Schauer, Easy Cases, $58 \mathrm{~S}$. Cal. L. Rev. 399 (1985).

64. The prevailing orthodoxy is that a presumption of constitutionality applies unless a particular enactment violates an enumerated fundamental right, affects a discrete and insular minority group, or affects the electorial process. See United States v. Carolene Products Co., 304 U.S. 144, 152 n.4 (1938). Recently, however, Justice Stevens argued that the refusal of government to regulate a particular action could be justified, if challenged, by a presumption of freedom: "Freedom is a blessing. Regulation is sometimes necessary, but it is always burdensome. A decision not to regulate the way in which an owner chooses to enjoy the benefits of an improvement to his own property is adequately justified by a presumption in favor of freedom." F.C.C. v. Beach Communications, Inc., -U.S._, 113 S.Ct. 2096, 2105 (1993) (Stevens, J., concurring). Whatever encouragement is provided by Justice Stevens concurrence is undercut by the opinion of Justice Thomas, which rests heavily on "a strong presumption of validity." Id. at 2102 . 
classical liberal natural rights theorist-even the most libertarian-has ever identified the liberty protected by natural rights with the freedom to do anything one wills. 65 There has always existed at least implicitly a distinction between liberty and license.66 So it is no infringement upon a person's natural rights to prevent her from violating the rights of another and the presumption of liberty would be inapt, except insofar as it is necessary to place the onus of proof on those who would argue that a particular type of action is violative of another's rights.

How is the baseline distinction between a rightful exercise of liberty (that is presumptively immune from governmental restriction) and a wrongful exercise of liberty (license) to be established, and by whom? Traditionally, this distinction between rightful and wrongful conduct was provided by the common law which determined a person's legal rights. Consider the following explication of the "common law" by Chancellor George Wythe, a distinguished judge and holder of the first Law Chair in the United States, in the case of Page v. Pendleton:

The position in the sixth article of our bill of rights, namely, that men are not bound by laws to which they have not, by

Ironically, given the fear that he would use natural law to strike down offending legislation, Justice Thomas enthusiastically embraced the prevailing view that

those attacking the rationality of the legislative classification have the burden

"to negative every conceivable basis which might support it" ... . Moreover, because we never require a legislature to articulate its reasons for enacting a statute, it is entirely irrelevant for constitutional purposes whether the conceived reason for the challenged distinction actually motivated the legislature. ... In other words, a legislative choice is not subject to courtroom fact-finding and may be based on rational speculation unsupported by evidence or empirical data.

Id. Justice Stevens took issue with this standard: "In my view, this formulation sweeps too broadly, for it is difficult to imagine a legislative classification that could not be supported by a 'reasonably conceivable state of facts.' Judicial review under the 'conceivable set of facts' test is tantamount to no review at all." Id. at 2106 n.3 (Stevens J., concurring).

65. Compare Robert Nozick, Anarchy, State, and Utopia 171 (Basic Books, 1974) ("My property rights in my knife allow me to leave it where I will, but not in your chest.") with Republica v. Oswald, 1 U.S. (1 Dall.) 319, $330 \mathrm{n} *$ (Pa. 1788) ("[T]hough the law allows a man the free use of his arm, or the possession of a weapon, yet it does not authorize him to plunge a dagger in the breast of an inoffensive neighbor." [statement of representative William Lewis to the Pennsylvania General Assembly]).

66. See, e.g., John Locke, Two Treatises of Government 288-89 (Peter Laslett ed., Cambridge U. Press, 2d ed. 1967).

But though this be a State of Liberty, yet it is not a State of License . . . The

State of Nature has a Law of Nature to govern it, which obliges every one: And

Reason, which is that Law, teaches all Mankind, who will but consult it, that

being all equal and independent, no one ought to harm another in his Life, Health, Liberty, or Possessions.

Although I disagree with the implications he draws concerning the role of judicial review, a recent insightful discussion of how natural rights theorists treated this issue is provided by Philip Hamburger. See Hamburger, 102 Yale L.J. at $922-953$ (cited in note 15). 
themselves, or by representatives of their election, assented, is not true of unwritten or common law, that is, of the law of nature, called common law, because it is common to all mankind. ... They are laws which men, who did not ordain them, have not power to abrogate. 67

That is, in contrast with constitutional law, which provides rules for the conduct of government agents, the common law of property, tort, contract, restitution, agency, etc. provides principles of right conduct to regulate the conduct of persons towards each other. For example, when one injures another and this injury is considered to be "tortious," then it is deemed to be wrongful and a duty to compensate is held to exist. A major portion of the first year of most law schools is devoted to studying the issue of rightful conduct. This body of rules and principles was at the time of the framing of the Constitution and largely remains almost entirely judge-made. Moreover, in the United States federal system it was and still is primarily made by state court judges. Even federal judges today acting pursuant to their powers in diversity cases attempt to discern state law and consider themselves bound by it. When federal judges must decide these state law questions in the absence of state court precedent, they may be "overruled" by subsequent state court decisions.

Thus there has evolved a division of labor. The judiciary in the several states were primarily responsible for determining rightful from wrongful conduct, while judges in the federal courts, beginning most famously with the case of $\mathrm{McC}$ Culloch $v$. Maryland, 68 were responsible for assessing the necessity and propriety of federal restrictions on otherwise rightful conduct. With the passage of the Fourteenth Amendment, the federal government's jurisdiction was expanded to include protecting citizens from rights infringements by their own state governments. ${ }^{69}$ This

67. Page v. Pendleton (1793), in George Wythe, Decisions of Cases in Virginia by the High Court of Chancery 214 n.(e) (B.B. Minor, ed., J.W. Randolph, 1852) as it appears in Sherry, 61 U. Cin. L. Rev. at 186 (cited in note 1). Cf. John S. Baker, Jr., The Natural and the Positive in American Law, in R.A. Herrera, James Lehreberger and M.E. Bradford eds., Saints, Sovereigns and Scholars: Studies in Honor of Frederick D. Wilhelmsen 157, 163 (Peter Lang, 1993) ("Originally common law was viewed as the embodiment of natural law. Then it became understood in historicist terms as simply custom and eventually in purely positivist terms as judge-made law.").

68. 17 U.S. (4 Wheat.) 316 (1819).

69. Thus the fact that the entire Bill of Rights, including the Ninth Amendment, was originally intended to apply only to the federal government-as the Supreme Court decided in Barron v. Baltimore, 32 U.S. (7 Pet.) 243 (1833)-does not mean that the Ninth Amendment is irrelevant to actions of state governments. Of necessity, the people retained their inalienable rights against the states as well as the federal government. This is evidenced by the swift incorporation of provisions similar to the Ninth Amendment into 
division of labor was not, of course, ever quite this neat. It was also thought appropriate for legislatures, especially on the state level, to intervene in the common law process, especially when the doctrine of precedent was thought to prevent a particular judicial reform.

Still, though this complicates the story a bit, it is important to bear in mind that such legislative interventions were supposed to be and in fact were comparatively rare. Determination of private rights were traditionally and remain overwhelmingly the province of state court judges. And, even with sweeping statutory innovation such as the Uniform Commercial Code, legislative alterations of private law rights remain relatively rare.70 Far more frequently has the common law been affected by the opinions of the non-profit American Law Institute through their highly authoritative series of "restatements" of the law.

So emerges the great outlines of an institutional allocation of responsibility in discerning and protecting the background natural rights of all persons: State common law processes determine the rights that each citizen enjoys against others, while state and federal judges are authorized to protect citizens from having these rights infringed by state and federal governments. Both components of this institutional division of labor have long existed.71

many state constitutions after Madison devised this express restraint. However, it was the Fourteenth Amendment that extended jurisdiction to the federal government to protect these rights from state government infringement, thereby altering the preexisting jurisdictional arrangement. This is not to claim that the Fourteenth Amendment somehow "incorporated" the Ninth, but that the Privileges or Immunities Clause extended the federal jurisdiction to protect the enumerated and unenumerated rights retained by the people against infringement by state governments.

70. It is a tricky, but necessary, business to distinguish those legislative actions that are a proper codification, regulation, systemization, or correction of common law rights from those that constitute state governmental interference with these rights. While this problem merits further discussion, it does not affect the efficacy of federal scrutiny of federal legislation that interferes with otherwise rightful exercises of liberty. Nor does it affect scrutiny of the clear majority of state actions that do not and cannot purport to be determining the private rights that citizens have against each other. This leaves only the important question of determining when state legislation purporting to improve upon the scheme of common law rights is actually infringing the relatively abstract background natural rights of its citizens. I do not think, however, that this question can be shirked solely because it may be difficult to identify a general theory that distinguishes genuine regulation from improper infringements of liberty. Without such a theory, citizens and their freedoms are left to the tender mercies of legislative majorities who may represent either majority or minority factions.

71. Professor Hamburger has recently offered an insightful interpretation of the relationship that the founding generation saw between natural and civil law. He notes that while Americans unquestionably conceived of freedom of speech as a natural right, they

frequently discussed the extent of freedom of speech and press without alluding to ideas of natural liberty or natural law. Sometimes, for example, Americans simply defined the freedom in terms of common law restraints upon it. Even 
My argument is that the legitimacy of the statute-making processes governed by the Constitution would be enhanced, however, if they are linked.

But does not this constitutional scheme place altogether too much power in state and federal judges? As I have already argued above, such reliance is unavoidable in a constitutional system in which courts are the only relatively "independent tribunals of justice" available to protect citizens from majority and minority factions operating through representative government. 72 Moreover, the problem is typically grossly overrated.73 When Congress disagrees with an assessment by the Supreme Court of the United States that its enactments have violated the background natural rights of the people, it has the power to propose a constitutional amendment. The President may take any disagreement (or agreement) with past Supreme Court rulings into account in selecting judicial nominees, and the Senate may express its views during the confirmation process. A majority of the Supreme Court may well protect rights at variance from the opinion of the overwhelming majority of the people for a time,

when Americans talked about the freedom of speech and press as a broader principle or generality, they often distinguished between liberty and license, without clearly alluding to natural rights or natural law.

Hamburger, 102 Yale L.J. at 953 (cited in note 15). The distinction between liberty and license needs to be defined conventionally because the concept of natural rights is too abstract to permit all but the most extreme of cases to be decided deductively from first principles. As Hamburger correctly observes, "being only a very abstract manner of reasoning, natural law was typically not understood to require the adoption of a particular set of civil laws. Moreover, though considered immutable, natural law was understood to permit variations in civil laws to accommodate the different circumstances in which such laws would operate." Id. at 937. However, because more than one set of legal rules is consistent with the abstract injunctions of natural rights, this does not mean that every set of legal rules is consistent. Particular common-law formulations can be criticized for being inconsistent with abstract natural rights and consequently unjust. The issue being discussed here, however, is who makes this decision, and traditionally this was primarily the province of state court judges, with occasional correction by state legislatures.

Where I part company with Professor Hamburger is over his claim that "[a] failure of the constitution to reflect natural law was a ground for altering or abandoning the constitution rather than for making a claim in court." Id. He has missed a crucial third possibility that was unlikely to have been missed by the framers, who had practiced civil disobedience long before they became revolutionaries: that the failure of a constitution to respect natural rights was a ground for disregarding laws that are promulgated pursuant to its authority.

72. Although this proposal makes the most out of the constitutional scheme that we currently have, it is not the only constitutional arrangement imaginable. I have speculated on more radical possibilities in Randy E. Barnett, Pursuing Justice in a Free Society: Part Two-Crime Prevention and the Legal Order, Crim. Just. Ethics, 30, 37-49 (Winter/ Spring 1986) (describing a polycentric legal order).

73. See Barry Friedman, Dialogue and Judicial Review, 91 Mich. L. Rev. 577 (1993) (arguing that courts are not systematically less majoritarian than the political branches of government). 
but life is alas all too short. This fact plus our method of judicial selection assures that, for better or worse, in the not-so-long run any opinion about the rights of the people which is opposed by an overwhelming majority of the people will be reversed.

These various mechanisms by which Supreme Court rulings protective of liberty can be challenged may take some time and effort to be effective, but this delay is in most instances salutary and, in any event, is absolutely essential if legislatures are not to be judges in their own cases when their acts restrict the liberty of citizens. The more likely deficiency of this proposal in practice is that government judges are not sufficiently independent of government or of a majority faction to provide "an impenetrable bulwark against every assumption of power in the legislative or executive." 74 For this reason prior rulings upholding the exercise of such powers should always be subject to reconsideration when circumstances have changed.

\section{CONCLUSION: THE LEGITIMACY OF LAW}

Let me summarize the analysis I have presented here. First, I contended that it is impossible to avoid getting normative about whether the unenumerated rights retained by the people merit judicial protection. For the legitimacy of the enterprise established by the Constitution depends on its ability to reliably produce enactments that bind the citizenry in conscience. And we cannot be sure that any enactment restricting the rightful liberty of a citizen has this binding quality unless we are certain that it has been scrutinized by an independent tribunal of justice to see if it is necessary and proper. Thus the background natural rights of all persons require that a burden should be placed on those who seek to restrict liberty to justify their actions, rather than on the citizen to justify her freedom. In our constitutional scheme, this can be accomplished by linking state law determinations of rightful conduct with state and federal scrutiny of legislative and executive restrictions of such conduct.

Although we may not wish to know how either laws or sausages are made, we had better be sure that the processes of both lawmaking and sausage-making include a quality-control mechanism that ensures that the product being purveyed is safe and

74. The phrase is, once again, Madison's. See 1 The Debates and Proceedings in the Congress of the United States at 457 (cited in note 36) (Statement of James Madison), reprinted in Barnett, 1 The Rights Retained by the People, at 51 (cited in note 38). See, e.g., Korematsu v. United States, 323 U.S. 214 (1944) (upholding the constitutionality of confining citizens of Japanese ancestry in detention camps). 
[Vol. 12:93

wholesome. That such quality-control processes are imperfect in no way undermines their importance. This is particularly true when - as was tragically demonstrated once again in Wacowhether dealing with food or force, life and death may hang in the balance. 